\title{
STORIES AND STORYTELLING FOR MORAL EDUCATION: KINDERGARTEN TEACHERS' BEST PRACTICES
}

\author{
${ }^{1}$ Maila D.H. Rahiem, ${ }^{2}$ Nur Surayyah Madhubala Abdullah, ${ }^{1}$ Husni Rahim \\ ${ }^{1}$ Universitas Islam Negeri Syarif Hidayatullah Jakarta, Indonesia \\ 2Universiti Putra Malaysia, Serdang, Malaysia \\ corresponding e-mail: mailadinia@uinjkt.ac.id
}

\begin{abstract}
Habituation is the most common used form of moral education in early childhood education in Indonesia. However, this method has been found to be insufficient in contributing fully to young children's moral development. An alternative method currently being promoted is the narrative method which involves the use of stories and storytelling. These two techniques provide children with justification to do good deeds and allow them to be critical of their actions. This research examined the best practices of teachers in the use of narrative method for the Moral Education of young children. Best practices show how we can use them to improve the teaching of Moral Education among young children and can serve as useful alternative to habituation. The findings revealed that there are five ways in which the kindergarten use stories and storytelling in teaching and learning moral education for young children, namely: to repeat the story; to include clear example; to explain the story; to dramatize the story; and to modify the story.
\end{abstract}

Keywords : Moral Education, Storytelling, Early Childhood Education, Teachers' Experiences

\section{Abstrak}

Pembiasaan adalah bentuk pendidikan moral yang paling umum digunakan dalam pendidikan anak usia dini di Indonesia. Akan tetapi, metode ini ternyata masih kurang memberikan banyak kontribusi dalam perkembangan moral Anak. Salah satu metode alternatif yang saat ini sedang banyak dikenalkan adalah metode naratif yang melibatkan penggunaan cerita dan bercerita (Storytelling). Dua tehnik ini memberikan dasar pembenaran pada anak-anak untuk melakukan perbuatan baik dan menjadikan mereka mampu bersikap kritis terhadap tindakan yang mereka lakukan. Penelitian ini menguji Pengalaman terbaik para guru dalam penggunaan metode naratif untuk pendidikan moral pada anak. Pengalaman terbaik ini menunjukan bagaimana metode tersebut dapat digunakan untuk meningkatkan pendidikan moral pada anak dan juga dapat digunakan sebagai salah satu alternatif proses pembiasaan pada anak. Hasil temuan menunjukan bahwa ada lima cara yang digunakan Taman Kanak-kanak (TK) dalam menggunakan cerita untuk proses belajar mengajar pendidikan moral pada anak-anak, yaitu dengan cara : mengulang cerita, memasukkan contoh yang jelas, menjelaskan cerita, mendramatisir cerita dan memodifikasi cerita

Kata kunci : Pendidikan Moral, Bercerita, Pendidikan Anak Usia Dini, Pengalaman guru 


\section{Introduction}

Indonesia became a signatory to the Millennium Development Goals (MDGs) in 2000. One of the objectives of the deal is to provide equal opportunities for education for all, and in 2019 Indonesia joined the group of countries with a high human development index, according to a report published by the United Nations Development Program or the UNDP on 9 December 2019 (UNDP, 2019). The Indonesian Government has increased efforts through various policies in education, economic, politic and social life to improve the quality of life of Indonesians. The provision of primary education for all is expected to increase welfare and eradicate poverty across the nation (Eryong \& Xiuping, 2018; Johnston, 2016). Education prepares students for the complexities of life in this era of new technology. Education should, therefore, be versatile and flexible so that it can be adjusted to respond to any changes that may occur, both quickly and responsibly. Due to this, education practitioners and policymakers need to be informed of expected global developments and tracked to enable the possibility of development. Proper education will generate valuable human resources required to develop the country further (Webb et al., 2018).

The urgent needs of this country are not only to provide the workforce with the appropriate skills and knowledge but also character building. In meeting these goals, one of the urgent needs is not only to develop workforce who have the relevant and appropriate knowledge and skills but also the character to ensure that the integrity of the work is sustained. The shift from knowledge-based and skill-based education to character-based education is a significant step in creating a responsible and dependable workforce.

The Education Unit Level Curriculum (KTSP) has been replaced by the 2013 curriculum, which began to be implemented in 2014. The emphasis of the 2013 Curriculum is on simplification and thematic-integrative efforts. The 2013 curriculum is set to produce a generation that is ready to face the future since the curriculum is designed to anticipate future developments.

The most recent national curriculum, the 2013 curriculum, has been implemented to meet future global challenges, namely, to ensure responsible and capable citizens (Regulation of the Minister of Education and Culture of the Republic of Indonesia Number 37 of 2018). The 2013 Education Curriculum promotes the development of learners optimally and provides the foundation for an Indonesian human being who can live as an individual and a citizen who is loyal, efficient, imaginative, inventive, and productive and capable of contributing to social, regional, state and world civilization. 


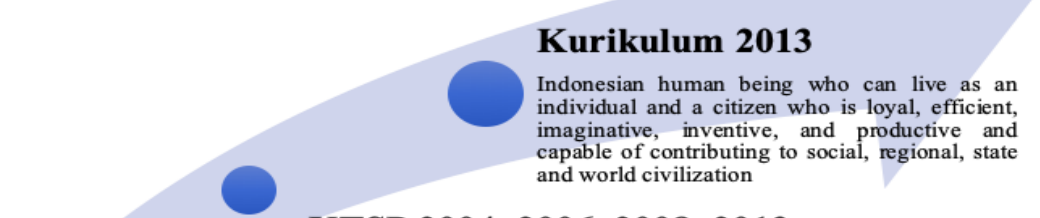

KTSP 2004, 2006, 2008, 2013

The shift from knowledge-based and skill-based education to character-based education is a significant step in creating a responsible and dependable workforce.

\section{Indonesia signed MDGs in 2000}

The provision of primary education for all is expected to increase welfare and eradicate poverty across the nation

Figure 1. MDGs \& Curriculum Changes

The 2013 Early Childhood Education Curriculum is designed with the following characteristics. First, this curriculum seeks to optimize the development of children, which includes: aspects of religious and moral values, physical-motor, cognitive, linguistic, social-emotional, and artistic aspects that are reflected in the balance of competence, knowledge, and skills. Second, the curriculum uses thematic learning with a scientific approach to stimulate education. Third, the curriculum uses authentic assessment to monitor the development of children. Finally, the curriculum empowers parents to play a role in the learning process (The basic framework and structure of the 2013 early childhood curriculum-Kerangka dasar dan struktur kurikulum PAUD 2013, 2014).

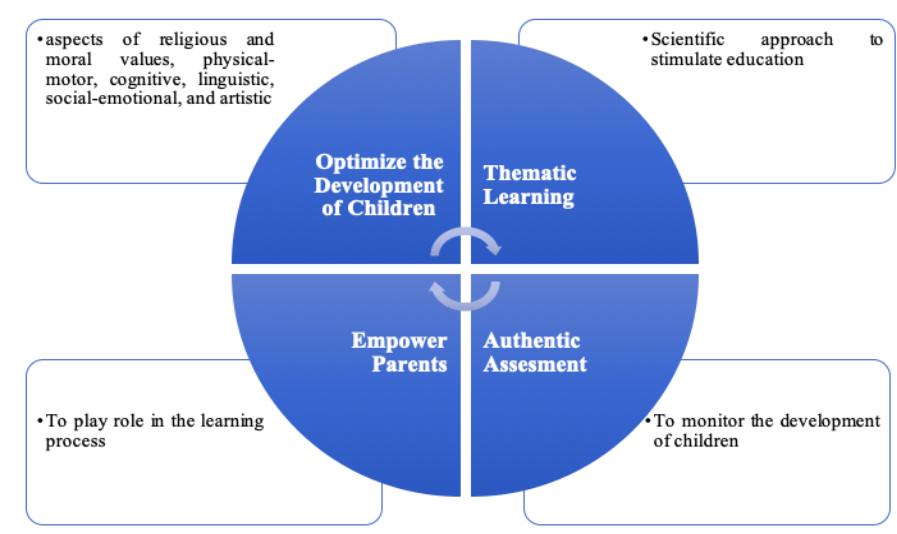

Figure 2. Characteristic of 2013 Early Childhood Education Curriculum

The scope of the kindergarten curriculum includes the following aspects of development: 1) moral and religious values; 2) social, emotional, and self-reliance; 3) language skills; 4) cognitive skills; 5) physical/motoric skills, and 6) art skills (Regulation of the Minister of Education and Culture of the Republic of Indonesia Number 146 of 2014). The program for the development of religious and moral values includes the embodiment of a learning atmosphere for the development of 
good behavior, which stems from religious and moral values and comes from community life in the context of the play.

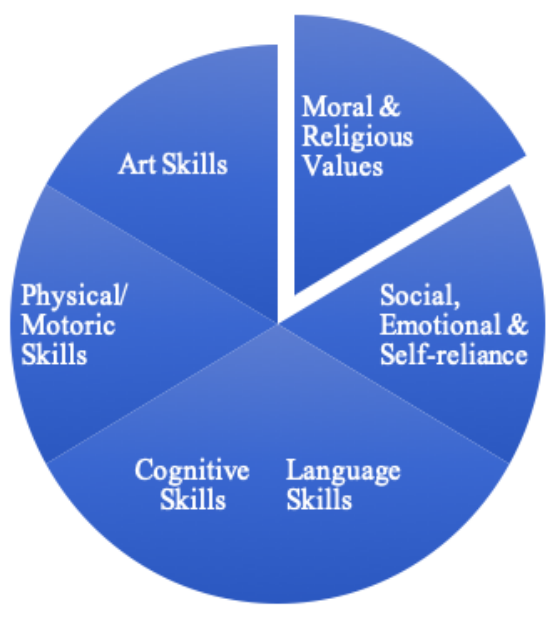

Figure 3. The Scope of 2013 Early Childhood Education Curriculum

The curriculum competence of early childhood education in the 2013 curriculum is the achievement of the standard level of child development at the end of early childhood services at the age of 6 (six) years. Core competencies include 1) spiritual behavior; 2) social attitudes; 3) knowledge; 4) skills. Core competencies in spiritual behavior include accepting the teachings of the religion they hold (The basic framework and structure of the 2013 early childhood curriculum-Kerangka dasar dan struktur kurikulum PAUD 2013, 2014) Core competencies in social attitudes include a healthy lifestyle, curiosity, creativity and artistic, trustworthy, disciplined, independent, caring, respectful and tolerant of others, adaptability, responsibility, honesty, humility, and politeness in interacting with family, teachers, and friends. Core competencies in knowledge include the ability to identify own self, family, friends, teachers, the environment, religion, technology, art and culture at home, playgrounds and early childhood education units by observing with the senses (seeing, hearing, smelling, feeling, touching); asking; gathering information; reasoning and communicating through play activities. Core competencies in skills include being able to show what is known, felt, needed, and thought through language, music, movement, and ready to work productively and creatively, and reflecting the behavior of noble children. 


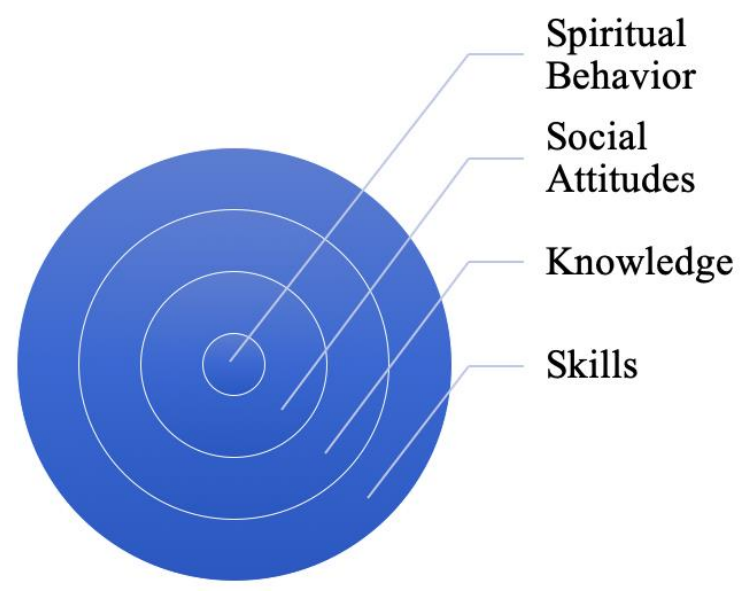

Figure 4. Core Competencies of Early Childhood Education

Moral education itself is taught not as an independent lesson, but as an integrated lesson with other subjects that cover the four core competencies of early childhood education. Most early childhood moral education programs are delivered through habituation programs. This habituation program is explained in detail in the previous curriculum for 2008 (Regulation of the Minister of Education and Culture of the Republic of Indonesia Number 58 of 2009). The goal of habituation development is to help the child understand the different issues of daily life, both at school and within the broader environment (family, friends, and community). The development of habituation covers aspects of moral development and religious values, as well as social and emotional development and self-reliance. Developmental issues include moral and spiritual values aimed at improving children's devotion to God and encouraging children's attitudes to help them become good citizens. Aspects of emotional and social development, on the other hand, aim to foster independence so that they can adequately control their emotions and interact well with peers and adults and help them develop their life skills.

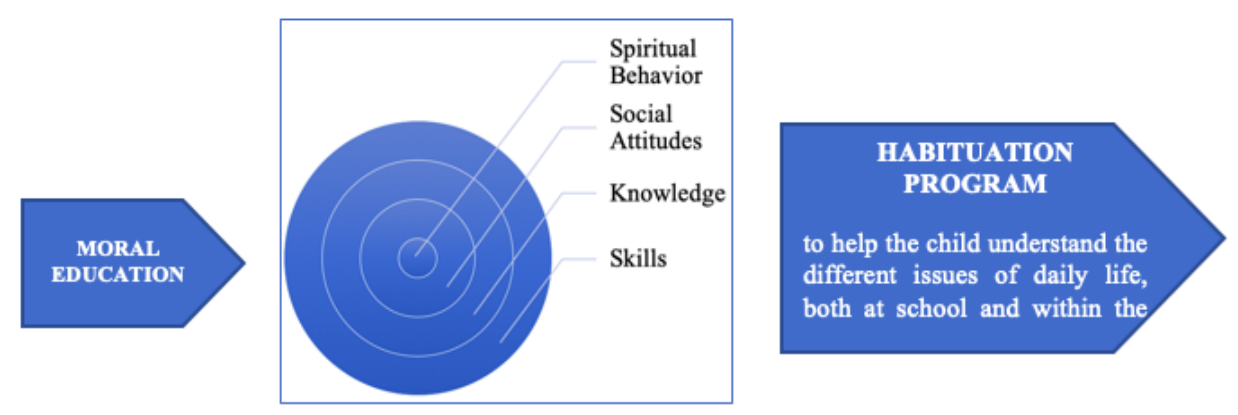

Figure 5. Moral Education in Early Childhood Education

However, this method does not seem to be sufficient to equip the child's moral development fully. The argument is that morality is not only about acting correctly; it is also about reasoning and feeling (May \& Kumar, 2018; Saunders, 2016; Sherman \& Guyer, 1995; Tangney et al., 2007). The habituation method only teaches the child to 
do things. Still, it is clear that not every child thinks about or understands their actions. Children need to learn how to think critically about the consequences of their actions. Children need to learn to act independently and not just to memorize the rules that may be dictated to them. As a result of this, alternatives to moral education are now commonly being offered through storytelling to teach children more than simply to be righteous people, but also to be responsible for their actions. Stories are believed to be able to explain why they need to do good deeds, and can even make children more critical of their actions.

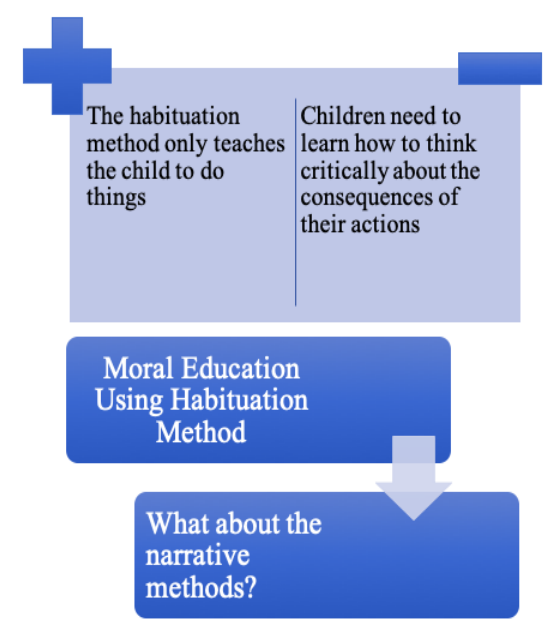

Figure 6. Habituation \& Narrative Methods for Early Childhood Moral Education

Extensive research and theories exist on how stories profess examples of the moral life (Gunnestad et al., 2015; McGinn, 1997; Rahim \& Rahiem, 2013; Thambu, 2017; Thompson, 2011; Winston, 2005; Woodard, 2005) Narrative techniques such as stories and storytelling in Moral Education guide young children to distinguish between what is right and what is wrong. Children's literature, such as fables, folk tales, and fairy tales, helps to interpret the underlying rules of society and guides the child to distinguish between right and wrong. Nevertheless, there remains a gap in the existing theory; empirical knowledge and practice that has prompted the effectiveness of the use of narratives in the teaching and learning of moral education for young children. There is a lack of empirical data in how teachers see and practice it. This research is expected to provide information on the existing practices of teachers in using narratives in teaching and learning moral education for young children and the techniques they have used the narrative in the teaching and learning of moral education in kindergarten.

In early childhood settings, particularly in the learning of values through storytelling, children are still very dependent on teachers in the learning. Most children in kindergarten are unable to read, and they need their teachers to read the stories. Teachers also need to help them understand the meaning of the stories. Narvaez argued that children develop moral literacy, not just by reading or listening 
to moral stories. Her arguments are: first, readers interpret texts in different ways because of their individual reading skills and the context of the information. Second, moral claims are also interpreted differently based on variations such as moral schema. Besides, readers have explained and weighted moral texts not in the same way, and this has been affected by their moral traditions. Finally, children usually understand a moral theme from the story, but this is not always the same moral as was initially intended by the author (Narvaez, 2002).

The ways teachers deliver stories affect the success of using storytelling for moral education. Specifically, young children's understanding of moral values in a story is influenced by the knowledge of the teachers on what the stories are used for in values education and the way the teacher tells the stories for that purpose, which is essential in facilitating the students to learn from the storytelling (Rahiem et al., 2017).

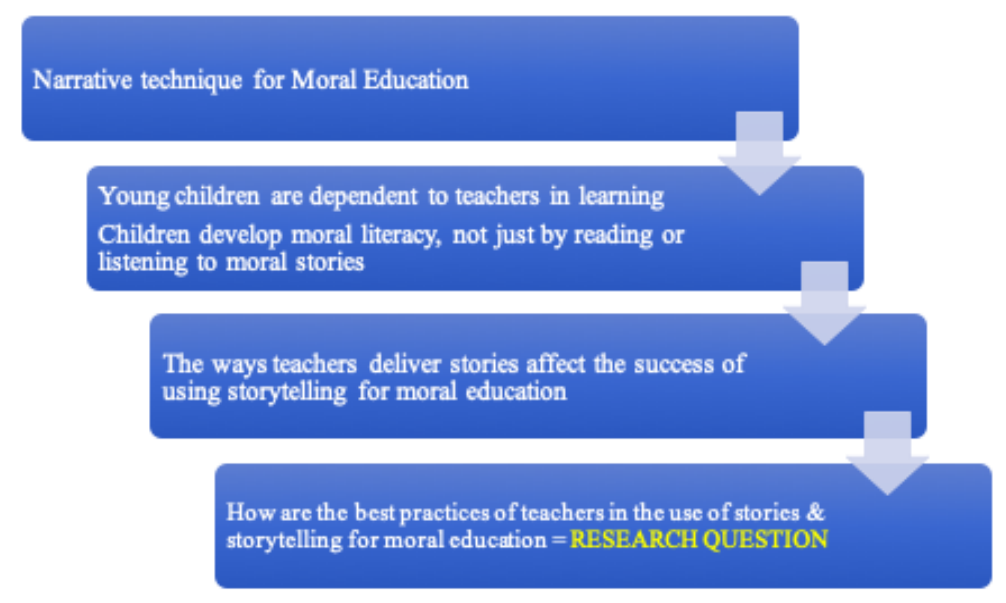

Figure 7. Formulation of Problem

It is, therefore, necessary to examine the best practices of teachers in the use of stories and storytelling for moral education. This research is expected to provide information on the kindergarten teachers' insights and observations on the best practices of the use of narrative technique in teaching and learning moral education for young children. Understanding the insights and observations of teachers on the technique can be useful to better integrate the narrative method to other methods of early childhood moral education (such as habituation) and to core competencies of the curriculum in order to address the demands of the 2013 curriculum.

\section{Methods}

Given the objectives of the study and the nature of its research questions, qualitative research is the method of investigation for this research. In quantitative research, researchers try to detach themselves as much as possible from research, while in qualitative research, researchers are intimately involved in the research 
(Nahid, 2003) The role of the researchers in this study is primarily that of the data collector. As a result, it will be possible to see the entire research process and also the research findings through the researchers' lens. The researchers played a pivotal role in the development of the research questions and the completion of the data collection, data analysis, and interpretation. The researchers used their values, but despite this, they always tried to remain as objective as possible. The researchers presented the entire research process as precisely and accurately as possible.

To better understand a particular phenomenon, purposive sampling was used in this research. The participants were selected according to the criteria or essential attributes embedded in the research questions (S. R. Jones, 2002). The participants of this study were selected for their sensitivity, knowledge, and insight into their experience. Although the decision to participate was strictly voluntary, the participants who chose to participate in this study appeared to match the defined criteria. The participants' criteria were that the teachers had been teaching for more than two years and used storytelling in their classrooms. They were well established in early childhood teaching and, therefore, were deprived of the nature of the interview questions posed by the researcher.

The total number of participants is 14 teachers from two kindergartens located in the South Jakarta area. Both kindergartens have been chosen as research sites because they have an excellent reputation within the community as a creative and innovative kindergartens. They have consistently and regularly incorporated storytelling activities into the student curriculum, while teachers use the storytelling method to learn. Teachers in both schools, therefore, have extensive experience of using storytelling as teaching tools. All participants use storytelling in their classrooms and have a favorable view of the use of storytelling in the teachinglearning process.

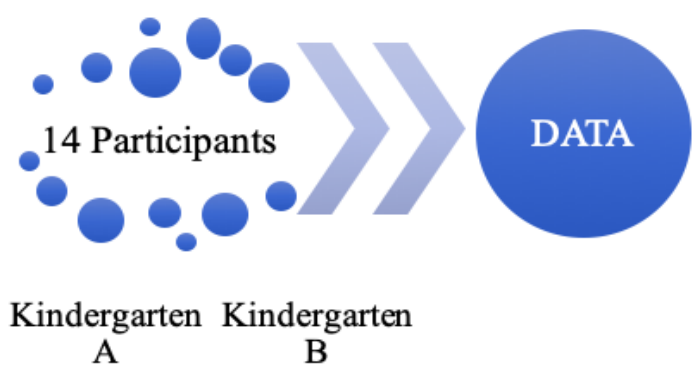

Figure 8. Samples

Coded names conceal the names of the teachers in order to preserve their identities and increase their confidence in talking about their knowledge, understanding, and practices in the use of stories and storytelling for moral education. T1 up to T14 are the coded names used. The actual names of the two kindergartens were also deliberately obscured in order to ensure further anonymity. 
The study used several data collection methods to obtain a rich and deeper insight into the studied phenomenon. Semi-structured, in-depth interviews, and focus groups were the primary method of data collection. More information was then also gathered through observation and document analysis.

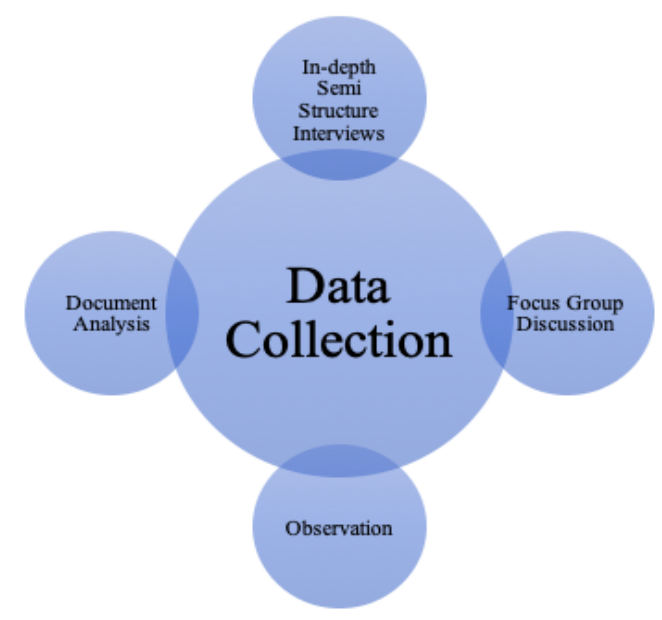

Figure 9. Data Collection Technique

The primary sources of analysis of the data in this study were spoken words, observations, and documents. Data analysis begins when data collection is started, not after all the data has been collected, as is the case in quantitative studies. Data analysis occurs simultaneously and interactively with data collection, data interpretation, and reporting (Creswell, 2002; Miles \& Huberman, 1984). The data analysis began by identifying the themes that emerged from the raw data. Strauss and Corbin, refer to the process as 'open coding.' At the next stage of the analysis, the researchers re-examined the categories identified in order to see the connection. This complex process is sometimes referred to as 'axial coding' (Corbin \& Strauss, 2014). Finally, the researchers then organized everything into a short piece of writing to ensure that the research is a vibrant, well-woven account that gives an accurate picture of the reality that was being studied.

The qualitative research involved a triangulation analysis, which included interviews with teachers, collection and analysis of documents, observations of how teachers selected stories and how they told stories, and an exploration of the teachers' understanding by having a focus group discussion (FGD) with the three keynote informants.

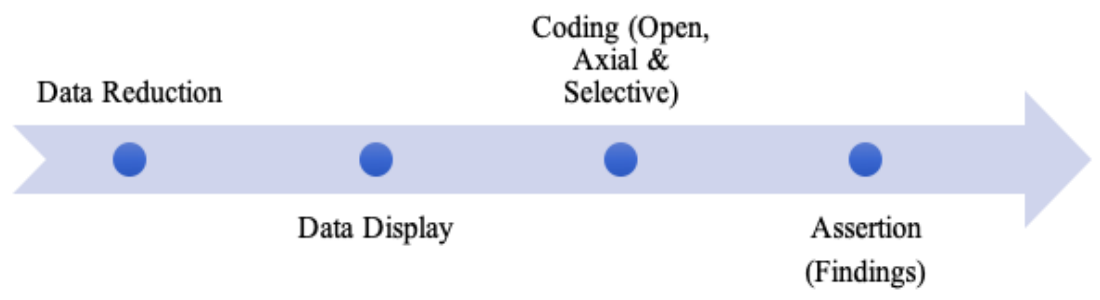

Vol. 2 No. 1 | 9-20 
Figure 10. Data Analysis Technique

All interviews were taped and transcribed to form the basis for subsequent analysis. These responses were then compared and contrasted in order to detect overall perceptions, commonalities, and differences and congruence with the subsidiary questions of this case study. In practice, the data analysis phases were carried out simultaneously and repeatedly. During axial coding, the researchers had to change earlier categories several times, re-examine raw data, and also look for additional data.

\section{Result and Discussion}

What are the best practices of using stories and storytelling in teaching and learning moral education to young children? The findings were grouped into five main themes, namely repetition, actual examples, discussion, dramatization, and modification.

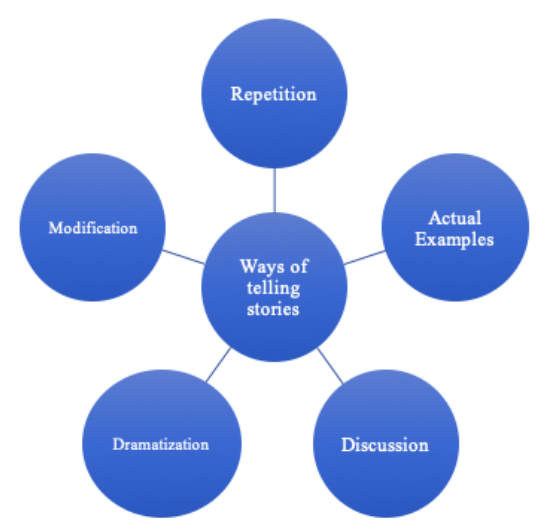

Figure 11. Research Findings

The first theme is repetition, what is meant by repetition is that when teachers use storytelling to teach and practice moral education, they do not only read or say a story once; they repeat it several times. During the second interview, T1 clarified that not only does she tell a story once, but she also repeats the story many times to make children understand and mirror what the characters do. She added that children tend to forget stories quickly, and they, therefore, understand the narrative better by repeating the story.

If we tell the children's story, we can't do it only once, it must be repeated often, we're going to re-tell the story. If we want to inspire children to want to eat vegetables, not just once, today we're going to say the story once, tomorrow we're going to tell something else, but a few days later, we're going to repeat the same theme, but maybe in a different way, so the story will be understood and it will then help the children to do as the characters do. We've told the story over and over again, so the kids seem to remember the story, because they're usually so quick to forget a story. (T1) 
Teachers also explained how they need to include concrete examples of actual conduct, not just by telling stories. The following statements explain how T4 assumed that children had to practice good deeds after hearing a story:

I believe that in the stories that children can learn, children should not only be instructed, but also practice instantly so that there is a consequence, for example, morality, several examples, if they have to be respectful to the elderly, so they must always be respectful to others, such as the assistant teacher. This could be educated through storytelling, followed by an example. (T4)

T6 explained his views of the best way to use storytelling to teach and teach young children moral education by telling stories and giving children real examples. T6 said that children need to experience it directly themselves before it inspires them to do good deeds. T6 pointed to the example of littering and having to clean the classroom and the toilet; if they experience cleaning the classroom and the toilet and know it is tiresome, then they will not be negligent with throwing litter in the future:

So, for moral education, firstly I use a storytelling technique. But, I believe the most successful approach is through direct experience. And if they've witnessed it explicitly, some of the students will say, why do we have to dispose of the waste? Why do we need to sweep up the classroom?" If children feel exhausted after cleaning the classroom, exhausted after cleaning the bathroom, they will not be irresponsible. (T6)

The teachers explained that a discussion during and after storytelling about the moral dimension of the story is necessary to help children understand the story and to make sure they interpret it as intended by the teacher. T4 defined the importance of holding a conversation during and after the narrative to help children understand the story:

We lead them, we help them to understand. I'm building a link with them when they ask a question, a dialogue, they get a role, and they're acting out some part of the story. If we want to know whether or not children understand our narrative, we should have a discussion... both during and after storytelling. (T4)

Teachers in this study said they often dramatized the story with mimicry, movements, intonation, and using technology. T11 clarified that the usefulness of the narrative in the propagation of moral values depends on the techniques used in telling a story. She said it is essential for teachers to tell a story appealingly so that kids will listen to it. Otherwise, they will not concentrate on the story, and they are unlikely to then get the message out of the story:

The success of the narrative in the development of moral principles depends on the manner in which the tale is told. Okay, I guess if the story is told by the teacher in a boring manner, children would definitely not want to listen and they won't understand as well. And, in essence, the most important way to do this is how the teacher tells the story. If teachers use different approaches or creative storytelling, kids typically react instantly, but if a teacher, sorry, for example, doesn't tell the 
story well, it's useless. That's according to my observation, so the main element is the teacher, if we want to teach moral values by stories, we should relate a story in an entertaining way, so that children can understand and respond directly. When they answer, we see how their interpretation is; it's nice if it's in line with the essence of the story, but if it's not, it's the teachers' responsibility to guide the students. (T11)

Based on the review of the results, the study found that teachers change the content of the story if they feel it is not suitable for young children. Teachers in this study change the story in order to comply with religious instructions and to protect children from violent and sexually explicit material.

T7 argued that when the story is told, the story must be modified when the story does not adhere to religious teaching. She said that children would find the Timun Mas story hard to understand since it makes no sense to pray to the giant for a child and to have a child born of cucumber seeds. It is easier for her to ask them to pray to God and make the story more realistic:

There are a number of versions of the Timun Mas narrative. In my view, fairy tales or myths rooted in or originating from Indonesia should be told or read aloud to children in kindergartens. But sometimes, we're not allowed to read or tell the tale as it is. There are certain elements in this story that are difficult for children to comprehend. For starters, the old lady prayed, not to God, but to the giant instead. This isn't right, she's expected to pray to God. As described in this story, the giant gave the mother cucumber seeds that grew larger later, and there was a baby inside. It's perfect for a fairy tale to have a plot like this. Yet if I read or hear this story, I'm going to change the story (giggling). (T7)

Overall, the research reveals that five key themes have been identified. These five principles describe the most common ways in which kindergarten teachers use storytelling for moral education.

The first theme of the results is repetition because teachers do not just read or say a story once; they repeat it a few times over a more extended period. Teachers have explained how they repeat the narration many times to ensure that children understand the story so that they can learn from the story. They also want to direct children to the correct interpretation or message of the story. It is in line with what Anderson \& Groft (1972) claimed that children could benefit from stories because stories have experience. Stories are a reflection of life and mind in the form of words. They said that stories affect the way children think and act. Children want to hear or read stories over and again, and they remember the specifics in the tales. This repetition, combined with the children's imagination, makes stories one of the best ways to stimulate thought. It is also reflected in the observations of Lartz \& Mason (1988), who performed a case study of a preliterate child's retelling of a story several times over eight weeks. The retellings were audiotaped and evaluated for improvement. They found that the story became the child's own story after retelling the story a handful of times. 
An important aspect was also found; the teachers said that they would repeat the story because they wanted the children to have the same understanding of the principles of the story as the teachers. T8 said that she would not stop telling the story until the children understood it as she wanted. T10 said that when kids did not understand, she would direct them right away. T3, T8, and T12 explained that they want to make sure that children explain what they understand so that they can clarify what the meanings of the story are. T1 and T14 explained that they wanted children to understand the story and better understand the meaning of the story. Such teachers guide and correct children's comprehension. Teachers like to see a child as a blank slate. They were born just to be morally neutral. Their personality can develop in infancy, and adults around them might have a very long-lasting effect on their personality. Many Muslims believe that children are born like a blank slate, as John Locke said (John Locke, n.d.). If the definition of faith misleads a child, it is the fault of culture or the social environment. This principle is also used in many popular parenting books in Indonesia (Noormindhawati, 2014; Rif'ani, 2013; Setyawan, 2015)

The teachers explained that real examples are needed. They said moral formation is not optimal by using storytelling only. Children at this age like to imitate things, they need to practice it and repeat the acts. This suggests similarities to Spiecker (2005), who proposed training, conditioning, and drilling are essential to early childhood upbringing and moral training. The teachers also described that kindergarten children need a concrete example because it is easier to grasp the idea, storytelling is considered abstract thinking. So, real examples help them to understand better. This statement is similar to what Piaget (2013) proposed in 1932; that young children are 'pre-moral' beings who are incapable of considering the perspectives of others or thinking abstractly. Kohlberg, (1976) also agreed with Piaget that children at the level I struggle to think abstractly, and this limits their ability to take the perspective of others. (Bebko et al., 1996) said that young children learn by imitating and modeling on an education role, which means that they observe around them without the need for instruction or telling. The data also indicated that teachers felt that kindergarten children needed specific examples because they still think onedimensionally, with storytelling considered to be abstract thinking.

These teachers said that moral development is not optimal by narrative usage only. Kids tend to mimic actions at this age, and they need to practice it and repeat the activities. This is similar to Spiecker (2005), who suggested that preparation, conditioning, and drilling are essential for early childhood education and moral preparation.

The seven teachers, who said they provided practical examples to children, graduated from early childhood education programs. Does their educational history affect their practice of providing specific examples to children? If we look at the 
framework of early childhood teaching courses in several universities (UIN Jakarta, UNJ, UKSW, and UPI), child development courses are one of the mandatory subjects, disciplines, and skills with a minimum of 6-8 credits. The theories of child development, like Piaget's theory, are explored in this course. The teachers' argument that children of kindergarten age need to benefit from examples because they still think one-dimensionally reflects Piaget's principle of child development. Piaget, in 1932 proposed that young children are 'pre-moral' creatures that are incapable of looking at the viewpoints of others or of thinking abstractly. If young children are limited in their moral skills, they can also be limited in their ability to interpret moral messages in stories. Kohlberg's work reinforced this view in 1976. Again, the researchers looked at the idea of children's learning in the kindergarten curriculum, and this interpretation of children's education in practical terms is also the theoretical foundation of the curriculum. Such teachers have a strong knowledge of the growth of children. It may be that their experience affects their understanding of child development. However, there should not be a generalization that all teachers that have studied early childhood education have more excellent knowledge than those who do not study this program. More in-depth studies and research would be required in order to arrive at these conclusions.

The data revealed that the teachers had conversations with the children during and after the storytelling. Not all teachers clarified the importance of the discussion, but the frequency of some teachers mentioning the word 'discussion' was high, e.g., T4 mentioned it six times, T7 three times, while six other teachers mentioned it twice. T4 argued that having a discussion during and after storytelling helped children to understand the story, to guide the children's understanding, to check the children's understanding, to ensure children do not misunderstand the story, to explain the teachers' understanding, and to build communication between storytellers and audiences. A necessary explanation for the teachers who lead the conversation during and after storytelling is that by creating empathy and engaging children in the story, children can remember the story, and this practice directs their comprehension.

The quote is a fascinating example of Vygotsky's conviction (Vygotsky, 1978; VYGOTSKY, 2019) that teachers should begin to learn from the stage where the learner learns. Teachers explain what to do, what to do next, and then inspire the learner to move on. Children rely on adults to keep going; teachers need to remind them about the social rules and explain the details to children. Penn (2008) commented that while Piaget and Kohlberg set aside the role of adults in the development of children, Vygotsky put them at the center. Also, Vygotsky argued that teachers ought to allow students to discuss their learning. The purpose of the discussion, he said, is to provide a meaningful dialogue between students and teachers that promotes a more profound understanding. Bruner (1966), who was 
influenced by Vygotsky, popularized the concept of 'scaffolding' to describe how adults are helping children learn. Bruner argued that the 'scaffold' guarantees that children are enabled by adults to grasp something. The scaffold will then only be removed when the student is ready. Teachers' activities in this research have shown that teachers ask questions and direct children before they understand the story and understand the moral meaning in the story correctly. The countless questions and conversations throughout and after storytelling are like a scaffold that protects and monitors the children step by step as they begin to learn.

Vygotsky and Bruner agree that learning is a very active process. It is different from the studied teachers' insights. Teachers in this research use scaffolding to ensure that the students have the same understanding as them. Bruner (1966) uses scaffolding differently. Teachers help children learn, help them understand, but teachers provide an opportunity for students to learn actively. They are forced to build their ideas and expertise based on their prior knowledge. It is important to review the best practice that the teachers interviewed stress in ensuring that children have the same understanding as they do. Teachers may help children understand stories in their own way and with their own interpretation. Children do not only have to do well; they need to understand their actions. Children need to learn to critically think about the implications of their actions.

Teachers in this study have said that the effectiveness of storytelling in communicating moral principles depends on how the story is told. Not only does this concept of dramatic storytelling come from one of two teachers who are also skilled storytellers, but almost all teachers have similar opinions. Only one teacher, T5, did not explain how storytelling are used for moral education by telling stories in dramatic ways. T5 looked nervous and uncomfortable during the interview, she kept on asking, "Am I doing it right?" Furthermore, she looked down and answered with a few short answers. When she recounted the story of Timun Mas, she also told it without much enthusiasm. That is different from other teachers who told the stories in dramatic ways. Her quiet and reserved disposition seemed to match the way she was telling a story.

Teachers discussed how, as storytellers, they would add some enthusiasm by using mimicking, accents, body language, props, and technology to tell the story. Bettelheim described making the story fun and exciting to keep the students' attention. Children understand the story and understand the meaning not just of the words spoken, but of the process of listening and internalizing the meaning. The teachers said that children could not understand when teachers read it as it is or said the story in an annoying way. When teachers read it dramatically, children learn meanings beyond text or phrases. The method of interpreting meaning from text follows the transactional theory of reading and writing by Rosenblatt (2019). In 
kindergarten, reading is performed by teachers, with students listening so that they generate understanding from what the teachers read or hear. Rosenblatt described how the reader uses the context of the text in a transactional process. It is an extraordinary experience in which the reader and the text consistently communicate, the essence of any text lies not in the letters printed, but in the interaction between the reader and the text. When the teachers tell the story, they always act on the story and include the children in the story. This practice is endorsed by Kristjánsson (2006), who noted that giving a child a chance to act on the role of a specific character with a different emotional temperament can be profoundly beneficial and that, in turn, children can better understand their potential. He added that by asking the child to behave like an angry person, it could enable children to understand how to deal with frustration in the future.

The other way that teachers use storytelling is by modifying the story. They clarified that when stories and storytelling are used for moral education, they change the unacceptable content. The teachers said that the content of the story should conform to religion and that religion influences the way teachers tell children's stories. Jasper (1992) said that all literature is religious, and that is equally true of quality children's books. There is a moral stance in every story that comes from convictions, religious or non-religious, or agnostic. We combine the knowledge we have obtained with what is already in us, as described in the Rosenblatt Transactional Theory. So, that they can relate the story to themselves and shape their value systems as described by Ago \& Stan (1995), children's spiritual self is nourished while reading a picture book. When they make connections with the characters in the novels, they strengthen their comprehension of themselves and others.

In addition to changing the story in order to comply with religion, three teachers explained about a revision of the plot, so that there was no violence or sexually explicit material. Kidd (2005) addressed how young people should be shielded from abuse and evil in literature. The teachers in this study commented on the folktale of Timun Mas as revealing the violence and wrongly answered prayers, not to God, but to a giant. They suggested not introducing folktales and fairy tales to the classroom because the stories do not make sense. While fairy tales frequently contain abuse, they still provide immeasurable value in a child's life. Trevarthen \& Aitken (2001) clarified that taking violence out of fairy tales will take away the potential that these stories have to help children communicate their inner terror. (Bettelheim, 2010) clarified that the dichotomy of right and wrong provides a child with experience in moral education. (Danilewitz, 1991) explained that the story would not be complete without the involvement of two competing powers, good and bad. He added the bad and the good, to include the moral background. Teacher practices are ideally suited to achieving the goals of the curriculum. The use of 
conflicting stories exposes children to a real-life situation. The alteration of the stories lets them concentrate on the good deeds on the stories.

\section{Conclusion}

The results showed that there are five ways in which the participants in this study use storytelling in teaching and learning moral education for young children, namely: to repeat the narrative, to provide specific examples; to discuss the story; to dramatize the story; to alter the story. The methods are not the same for each person, but they are a collection of strategies revealed at the time of the individual interviews and the FGD. Just one participant did all of the above methods, while the other participants did around three or four of the above methods. The findings of this study have generated several recommendations for potential areas for future research: First, expanding the study of how kindergarten teachers use storytelling for moral education in other study locations, as it is vital to improving the standard of moral education in the kindergarten across Indonesia by learning from the best practices of the experienced teachers. Second, in particular, the results of this study open up new agendas for future studies. For example, how the role of teachers in teaching and learning influences children's comprehension and moral development, research what books are ideally suited to teaching children's values, or the most suitable storytelling technique for successful moral education. Third, expanding studies among other study participants, such as moral education teachers in primary or secondary schools who use storytelling for moral education. Fourth, engaging kindergarten students as participants in the triangulation analysis in order to achieve a thorough understanding of and recognition of moral values. Lastly, for researchers wishing to perform a quantitative analysis, this study may be used as a guide in the development of instruments to survey a more significant number of samples.

\section{References}

Ago, H. C., \& Stan, S. (1995). Religious Topics in Children' s Literature. XV(1), 91-97.

Anderson, W., \& Groft, P. (1972). A new look at children's literature. Wadsworth Publishing Co., Inc.

Bebko, J. M., Perry, A., \& Bryson, S. (1996). Multiple method validation study of facilitated communication: II. Individual differences and subgroup results. Journal of Autism and Developmental Disorders. https:/ / doi.org/10.1007/BF02276233

Bettelheim, B. (2010). The uses of enchantment: the meaning and importance of fairy tales. Vintage Books.

Bruner, J. . (1966). Toward theory of instruction. Harvard University Press.

Corbin, J., \& Strauss, A. (2014). Basics of Qualitative Research: Techniques and Procedures for Developing Grounded Theory (4th ed.). Sage. 
Creswell, J. W. (2002). Research design: qualitative, quantitative, and mixed methods approaches. Sage Publication.

Danilewitz, D. (1991). Once upon a time..... The meaning and importance of fairy tales. Early Child Development and Care, 75(1), 87-98. https:/ / doi.org/10.1080/0300443910750104

Dinia Husni Rahiem, M., Surayyah Madhubala Abdullah, N., \& Eric Krauss, S. (2017). Kindergarten Teachers and Moral Education for Young Children: Why Do Narratives Matter? Proceedings of the 3rd International Conference on Early Childhood Education (ICECE 2016), 301-306. https://doi.org/10.2991/icece16.2017 .52

Eryong, X., \& Xiuping, Z. (2018). Education and anti-poverty: Policy theory and strategy of poverty alleviation through education in China. Educational Philosophy and Theory, 50(12), 1101-1112. https:/ / doi.org/10.1080/00131857.2018.1438889

Gunnestad, A., Mørreaunet, S., \& Onyango, S. (2015). An international perspective on value learning in the kindergarten - exemplified by the value forgiveness. Early Child Development and Care, 185(11-12), 1894-1911. https:/ / doi.org/10.1080/03004430.2015.1028384

Jasper, D. (1992). The Study of Literature and Religion. Palgrave Macmillan UK. https:/ / doi.org/10.1007/978-1-349-22124-0

John Locke. (n.d.). Stanford Encyclopedia of Philosophy. Retrieved April 28, 2020, from https:// plato.stanford.edu/entries/locke/

Johnston, R. B. (2016). Arsenic and the 2030 Agenda for sustainable development. Arsenic Research and Global Sustainability - Proceedings of the 6th International Congress on Arsenic in the Environment, AS 2016, 12-14. https://doi.org/10.1201/b20466-7

Jones, S. R. (2002). (Re)writing the word: Methodological strategies and issues in qualitative research. Journal of College Student Development.

The basic framework and structure of the 2013 early childhood curriculum (Kerangka dasar dan struktur kurikulum PAUD 2013)., Pub. L. No. 146 (2014).

Kidd, K. B. (2005). \&quot;A\&quot; is for Auschwitz: Psychoanalysis, Trauma Theory, and the \&quot;Children's Literature of Atrocity\&quot; Children's Literature. https:/ / doi.org/10.1353/chl.2005.0014

Kohlberg, L. (1976). Moral stages and moralization: The cognitive-developmental approach. In Moral development and behavior: Theory, research and social issues. https:/ / doi.org/10.1017/CBO9781107415324.004

Kristjánsson, K. (2006). Habituated reason:Aristotle and the 'paradox of moral education.' Theory and Research in Education. https:/ / doi.org/10.1177/1477878506060699 
Lartz, M. N., \& Mason, J. M. (1988). Jamie: One child's journey from oral to written language. Early Childhood Research Quarterly. https://doi.org/10.1016/08852006(88)90022-1

May, J., \& Kumar, V. (n.d.). Moral reasoning and emotion. In K. Jones, M. Timmons, \& A. Zimmerman (Eds.), The Routledge handbook of moral epistemology (pp. 139156). Routledge.

McGinn, C. (1997). Ethics, Evil and Fiction. Oxford University Press.

Miles, M. B., \& Huberman, A. M. (1984). Qualitative Data Analysis: Handout. A Sourcebook of New Methods. California; SAGE Publications Inc.

Nahid, G. (2003). Understanding reliability and validity in qualitative research. The Qualitative Report, 8(4), 597-607. http://www.nova.edu/ssss/QR/QR84/golafshani.pdf

Narvaez, D. (2002). Does reading moral stories build character? In Educational Psychology Review. https:/ / doi.org/10.1023/A:1014674621501

Noormindhawati, L. (2014). The secret of millionaires to educate children (Rahasia para miliuner mendidik anak). Elex Media Computindo.

Penn, H. (2008). Understanding early childhood: issues and controversies. McGraw-Hill Education.

Piaget, J. (2013). The moral judgment of the child. In The Moral Judgment of the Child. https:/ / doi.org/10.4324/9781315009681

Rahim, H., \& Rahiem, M. D. H. (2013). The Use of Stories as Moral Education for Young Children. International Journal of Social Science and Humanity, 2(6), 454458. https://doi.org/10.7763/IJSSH.2012.V2.145

Regulation of the Minister of Education and Culture of the Republic of Indonesia Number 58 of 2009

Regulation of the Minister of Education and Culture of the Republic of Indonesia Number 146 of 2014

Regulation of the Minister of Education and Culture of the Republic of Indonesia Number 37 of 2018

Rif'ani, N. (2013). The Prophet's Example in Educating Children (Teladan Rasulullah dalam Mendidik Anak). Semesta Hikmah.

Rosenblatt, L. M. (2019). The Transactional Theory of Reading and Writing. In M. R. Ruddel \& H. Singer (Eds.), Theoretical Models and Processes of Literacy (pp. 451479). International Reading Association. https:/ / doi.org/10.4324/9781315110592-28

Saunders, L. F. (2016). Reason and emotion, not reason or emotion in moral judgment. Philosophical Explorations, 19(3), 252-267. https:/ / doi.org/10.1080/13869795.2016.1212395

Setyawan, A. (2015). Children are also human (Anak juga manusia). Noura Books. 
Sherman, N., \& Guyer, P. (1995). Reasons and Feelings in Kantian Morality. Philosophy and Phenomenological Research, 55(2), 369. https:/ / doi.org/10.2307/2108554

Spiecker, B. (2005). Habituation and training in early moral upbringing. In Virtue Ethics and Moral Education. https:/ / doi.org/10.4324/9780203978368-27

Tangney, J. P., Stuewig, J., \& Mashek, D. J. (2007). Moral Emotions and Moral Behavior. Annual Review of Psychology, 58(1), 345-372. https://doi.org/10.1146/annurev.psych.56.091103.070145

Thambu, N. (2017). Storytelling and Story Reading: A Catalyst for Inculcate Moral Values and Ethics among Preschoolers. International Journal of Academic Research in Business and Social Sciences, 7(6). https://doi.org/10.6007/IJARBSS/v7i6/3143

The basic framework and structure of the 2013 early childhood curriculum - Kerangka dasar dan struktur kurikulum PAUD 2013, 2014.

Thompson, M. (2011). Developing moral values in children: Observations from a preschool. IFE PsychologIA, 19(2), 394-411. https:// doi.org/10.4314/ifep.v19i2.69584

Trevarthen, C., \& Aitken, K. J. (2001). Infant Intersubjectivity: Research, Theory, and Clinical Applications. Journal of Child Psychology and Psychiatry, 42(1), 3-48. https:/ / doi.org/10.1111/1469-7610.00701

UNDP. (2019). Human Development Report. http://hdr.undp.org/en/countries/profiles/IDN

Vygotsky, L. (1978). Interaction Between Learning and Development. Harvard University Press.

VYGOTSKY, L. S. (2019). Interaction between Learning and Development. In Mind in Society. https://doi.org/10.2307/j.ctvjf9vz4.11

Webb, M., Kuntuova, I., \& Karabayeva, A. (2018). The role of education in realising youths' human capital: Social philosophical analysis. Ensaio. https://doi.org/10.1590/S0104-40362018002601727

Winston, J. (2005). Drama, narrative and moral education: Exploring traditional tales in the primary years. In Drama, Narrative and Moral Education: Exploring Traditional Tales in the Primary Years. https://doi.org/10.4324/9780203975497

Woodard, J. (2005). Head, Heart and Hands: Waldorf Education. Journal of $\begin{array}{llll}\text { Curriculum } & \text { 2(2), }\end{array}$ https://doi.org/10.1080/15505170.2005.10411551 